\title{
The Effect of Flipped Classroom Instruction on Developing Saudi EFL Learners' Comprehension of Conversational Implicatures
}

\author{
Nuha Abdullah AlSmari ${ }^{1}$ \\ ${ }^{1}$ College of Science and Humanities, Prince Sattam bin Abdulaziz University, Al-Kharj, Saudi Arabia \\ Correspondence: College of Science and Humanities, Prince Sattam bin Abdulaziz University, Al-kharj, Saudi \\ Arabia.E-mail: n.alsmari@psau.edu.sa
}

Received: December 26, 2019

Accepted: January 28, 2020 Online Published: February 5, 2020

doi:10.5539/ijel.v10n2p107

URL: https://doi.org/10.5539/ijel.v10n2p107

\begin{abstract}
While pragmatic instruction has received considerable attention from researchers of interlanguage pragmatics over the last three decades, its effective implementation in the EFL classroom remains an unresolved question. The flipped classroom model is a recently developed teaching method that constitutes a role change for teachers and learners, inverting the front-of-class instruction paradigm in favor of active and collaborative classroom learning. To potentially take advantage of this promising trend, the present study seeks to explore the effectiveness of the flipped classroom for developing Saudi EFL undergraduates' pragmatic competence and language proficiency by focusing on the comprehension of conversational implicatures during one academic semester. A total of 100 students, assigned to flipped teaching group $(\mathrm{n}=50)$ and traditional teaching group $(\mathrm{n}=50)$, participated in the study. To elicit the required data, the Oxford Placement Test, a discourse completion test, and reflective e-portfolios were used. A post-test revealed that pragmatic competence significantly increased in the case of the flipped group. The mean score of the flipped group $(\mathrm{M}=18.48)$ was considerably higher than that of the traditional group $(\mathrm{M}=14.68)$. In following the flipped model of instruction, this progress was influenced by effective out-of-class preparation and appropriate manipulation of in-class time.
\end{abstract}

Keywords: English as a foreign language, flipped classroom, pragmatic instruction, conversational implicatures, Edmodo

\section{Introduction}

Over the past three decades, pragmatic competence, i.e., "the ability to comprehend and produce meaning in context" (Taguchi, 2008, p. 433) has been conceptualized as an essential component within the field of second language acquisition (SLA) and an integral part of communicative competence frameworks (Bachman, 1990). From a pragmatic viewpoint, successful and effective communication in a second/foreign language (L2/FL) involves not only familiarity with the linguistic inputs in a given language but also pragmatic knowledge, which includes the ability to use and interpret these inputs appropriately in accordance with various social and cultural settings within a specific community (Bardovi-Harlig, 2013). This requires language learners, on the one hand, to be capable of using the language in accordance with the norms of the target community and with the norms of communication with various interlocutors. On the other hand, they ought to possess certain perceptions, knowledge, and skills to perceive cultural differences and to partake in intercultural contributions (Sánchez-Hernández \& Alcón-Soler, 2019). Recent evidence has further affirmed that some pragmatic functions and relevant contextual factors are often not sufficiently salient to be noticed by learners despite prolonged exposure in naturalistic settings with native speakers (Taguchi, 2019), whereas native speakers are less tolerant of violations of these pragmatic functions. Unlike grammatical errors, pragmatic errors are more likely to result in face-threatening situations in which FL speakers might be deemed uncooperative or inconsiderate (Bardovi-Harlig, 2013).

A compelling body of evidence has shown that formal instruction on pragmatic aspects is related to the subsequent acquisition of these aspects (Takahashi, 2010b; Bardovi-Harlig, 2010; Taguchi, 2019). Major conclusions drawn by prior studies (for reviews, see Taguchi, 2015; Plonsky \& Zhuang, 2019) reveal that learners who received classroom pragmatic instruction surpassed those who were non-instructed or those who were merely exposed to the same target language (TL) elements in L2 communities. The need for pragmatic instruction is commonly asserted in EFL contexts, in which FL students face two problematic issues that make it 
fairly difficult for them to gain pragmatic knowledge without formal instruction and more likely to commit pragmatic errors in their TL interactions. First, the teaching practices are traditionally grammar-oriented rather than focusing on appropriate context-based usage. Second, the opportunities for processing sufficient authentic input are marginal as the classroom constitutes the only setting for communication, and it is mostly teacher-centered (Bardovi-Harlig, 2013; Plonsky \& Zhuang, 2019). The focus of the study, pragmatic inferential skills, also called implicatures, are claimed to be only slowly learned in L2 settings unless they are explicitly taught. Furthermore, learners' cultural background is seen as a reliable predictor of their potential to perceive implicatures the ways native speakers do (Bouton, 1994b; Lee, 2002; Taguchi, 2008, 2019). However, interventional pragmatic studies that explore the teachability of conversational implicatures in FL settings are still lacking even though they have proven to be challenging for both SL and FL learners to interpret even after extended TL exposure (Bouton, 1994a; Taguchi, 2015; Plonsky \& Zhuang, 2019). With regard to the study context, no study has yet been carried out on Saudi EFL learners' comprehension of conversational implicatures. Notwithstanding that implicatures are a part of everyday interaction and implied meaning requires cultural knowledge for its interpretation (Bouton, 1994a; Taguchi, 2019), teachers ought to draw upon innovative approaches that can help EFL learners become more aware of pragmalinguistic and sociopragmatic features of pragmatic inferential skills (Taguchi, 2019).

With the advances in information technology and the introduction of web technologies, the platform of learning has expanded to include e-learning tools and virtual environments, allowing instruction to extend beyond the classroom walls. According to the 2012 Horizon Report, the flipped classroom approach (also referred to as the inverted classroom) constitutes a promising technological model in the educational field and particularly in higher education, where the traditional learning environment and its activities are frequently reformed (Johnson, Adams, \& Cummins, 2012). The flipped classroom pedagogical approach was initiated to open doors for teachers to manipulate the learning process for the benefit of learners in terms of both the quantity and quality of input to which they are exposed, transforming them from passive to active learners (Davies, Dean, and Ball, 2013). Flipped learning is assumed to be of great benefit for FL contexts in particular as it fosters two crucial aspects for successful language acquisition: student-centered learning and autonomy (Amiryousefi, 2017; Han, 2015).

While the flipped model of instruction has been introduced in a wide range of disciplines (math, social sciences, humanities, etc.) and educational contexts, including schools and universities (Hao, 2016; Bergmann \& Sams, 2012), few research studies have been carried out on the effect of flipped learning in FL classes (Alsowat, 2016; Alharbi, 2015; Chen Hsieh, Wu, \& Marek, 2017; Hung, 2017), which makes it scientifically impossible to draw general conclusions about this technique at present (for a review, see Turan \& Akdag-Cimen, 2019). In the same vein, Ekmekci (2017) explicitly stated that "studies on flipped classroom are limited, but studies on flipped language learning classrooms are much more limited" (p. 155). To the best of the researcher's knowledge, no study has explored the effectiveness of the flipped approach on pragmatic competence, except for the study of Haghighi, Jafarigohar, Khoshsima, and Vahdany (2019), which examined the effect of flipped learning on EFL learners' appropriate use of refusals via the telegram application. Regarding the target feature under study, far too little attention has been paid to the teachability of pragmatic implicatures, also referred to as implied meaning, in FL classrooms. What distinguishes this study from previous research is the target pragmatic element under investigation, that is, conversational implicatures. In addition, it explores the applicability of the Edmodo platform in the flipped classroom as an online course content delivery system. In addition, literature on mobile-based technology in language learning setting is scarce (Pimmer, Mateescu, \& Gröhbiel, 2016), and the effect of Edmodo in promoting pragmatic knowledge remains unexplored. In the light of the above-mentioned disregard of pragmatics in FL teaching and owing the positive outcomes of the flipped model of instruction, this investigation fills a research gap by exploring the effectiveness of the flipped classroom on Saudi EFL students' comprehension of conversational implicatures over an entire semester.

\subsection{Statement of the Problem}

Although pragmatic competence has been recognized as one of the cornerstones of effective communication in a second/foreign language (L2/FL), it has commonly remained neglected in the EFL Saudi classrooms, prompting students to construct their own assumptions and interpretations of L2 pragmatic behavior based on their L1 culture. This lack of attention is likely to have the opposite effect on students' pragmatic competence in particular and communicative competence in general, resulting in gaps of knowledge between the linguistic form "what is said" and communicative function "what is meant". Thus, Saudi EFL students appear to struggle with pragmatic comprehension and are more likely to commit pragmatic errors by unconsciously violating the social appropriateness of communication in the target language. This may be attributed to several reasons including the 
traditional teacher-led instruction which depends mainly on lecturing, lack of effective integration of technology, insufficient authentic language exposure as well as limited opportunities for classroom practice. In this respect, EFL teachers are challenged to help their FL students become more pragmatically competent especially when the input exhibited in textbooks don't commonly utilize target pragmatic features and don't reflect real-life conversations (Bardovi-Harlig, 2013; Taguchi, 2015; Plonsky \& Zhuang, 2019). Given the promising results of the flipped classroom model on EFL learners' performance, engagement and participation in the classroom as mentioned in the above literature, the present study aimed to determine whether the flipped classroom model can promote Saudi EFL students' pragmatic knowledge through increasing their level of engagement in the learning process, integrating means of technology effectively and creating more opportunities for meaningful interaction and practice during regular classes.

\subsection{Questions of the Study}

The current study seeks answers to the following questions:

1) What is the effect of a flipped classroom instruction on developing Saudi EFL learners' comprehension of conversational implicatures?

2) To what extent, if any, does the mode of instruction (flipped vs. traditional) influence pragmatic gains in the comprehension of conversational implicatures?

3) How does the flipped classroom model affect students' level of participation with the course content inside and outside the classroom?

\section{Literature Review}

\subsection{Pragmatic Instruction in the EFL Context}

Empirical investigations on the teachability of pragmatics date back to the 1980s. A plethora of experimental studies have been conducted to date on the performance of different pragmatic features and speech acts, such as requests, apologies, refusals, compliments, and complaints, in the L2 context (for reviews, see Takahashi, 2010a, 2010b; Hazaymeh \& Altakhaineh, 2019; Wafa' \& Altakhaineh; 2019; Haghighi et al., 2019). Many have conclusively reported that pragmatic competence can indeed be fostered through instruction; however, the level of pragmatic development is subject to the pragmatic aspect under investigation, contextual factors, and individual differences of learners (Taguchi, 2008; Sánchez-Hernández \& Alcón-Soler, 2019). Accordingly, there has been a vast proliferation of interlanguage pragmatic (ILP) research aimed at developing pragmatic knowledge in short- and long-term instructional classroom-based settings in the field of foreign language teaching and learning (for reviews of ILP research, see Taguchi, 2015; Plonsky \& Zhuang, 2019).

This stream of research has explored the impact of a variety of contextual factors that may influence the learnability of L2 pragmatics, including motivation (e.g., Takahashi, 2010b), language proficiency (e.g., Takahashi, 2010a), learning environment (e.g., Roever, 2012), length of residence in a TL country (e.g., Hernández \& Alcón-Soler, 2019), and emotional intelligence (e.g., Rafieyan et al., 2014). A small portion of this body of research, however, has been devoted to the area of comprehension of implicatures, the focal point of this study. Most of these experiments were mainly cross-sectional and developmental (Bouton, 1994a; Ying, 2001; Taguchi, 2008, 2019; Takahashi, 2010a; Bardovi-Harlig, 2013).

As pragmatic competence attracted more attention, researchers in the field began to investigate the effectiveness of various teaching approaches and compared the advantages of some instructional methodologies over others, including explicit and implicit instruction, input- and output-based teaching, skill acquisition and practice, and metapragmatic discussion (e.g., Fordyce, 2014). A number of studies have further attempted to explore the incorporation of recent technological advances for the teaching of L2 pragmatics (e.g., Takahashi, 2010a; Alcón-Soler \& Pitarch, 2010). The primary goal of these pragmatic classroom-based interventions is threefold: first, to develop FL learners' intercultural communicative competence; second, to reduce the possibilities of pragmatic failures and cross-cultural misunderstandings, especially when the exposure to target pragmatic features for a long period of time alone does not guarantee awareness nor acquisition of these features; and third, to help learners practice those pragmatic aspects being taught in real communicative environments (Bardovi-Harlig, 2013; Taguchi, 2019). Formal classroom-based instruction can help to remedy some of the drawbacks of being in a foreign language classroom when it comes to learning pragmatics. Pragmatics, like grammar and lexis, should be embedded into classroom pedagogy, and instructive pragmatic studies are increasingly required in the field of ILP, particularly in foreign-language contexts (Taguchi, 2019).

Acknowledging that the pragmatic advantages of classroom-based instruction are subject to the targeted pragmatic element under study and to contextual variables, including level of proficiency, teaching methodology, 
and learners' individual differences (Hernández \& Alcón-Soler, 2019), the current study seeks to examine the influence of the interaction of the contextual variable of the flipped classroom with the complex construct of the targeted aspect, that is, conversational implicatures, on Saudi EFL students' ability to recognize conversational implicatures. A discussion of the theoretical background of conversational implicatures and relevant research followed by a review of previous literature on the flipped model of instruction and its application in language learning classrooms are presented below.

\subsection{Comprehension of Conversational Implicature}

Speakers of any language occasionally use less straightforward communicative devices to convey their intentions, and they assume their hearers will deduce these messages appropriately (Thomas, 1995). Pragmatic comprehension requires the ability to comprehend these implied speaker meanings, known as implicatures, as opposed to literal meanings. Implicature is described as the additional conveyed meaning that must be interpreted on the basis of contextual knowledge in order to be understood (Yule, 1996). According to Grice (1975), implicatures are built on certain guidelines or maxims of conversational behavior. These guidelines fall into what he identified as the cooperative principle. That is to say, interlocutors involved in a conversation are normally expected to cooperate with each other by being informative, telling the truth, being relevant, and trying to be brief and clear. These rules serve to guide participants in the efficient and effective use of language in the pursuit of cooperative goals. However, when speakers violate the maxims of the cooperative principle and produce meaning that lacks these characteristics, listeners have to infer the intended meaning in order to understand what is implicitly communicated but not said (Bouton, 1994b). Messages obtained in this manner are referred to as implicatures, while with the process that generates them is referred to as implicature.

Grice (1975) classifies implicatures into two categories: conversational and conventional. The latter are inferences based solely on the use of certain linguistic forms, whereas the former, contrary to conventional implicatures, are more context-dependent and derived from knowing the maxims that rule conversation. For the purposes of the study, conversational implicatures are taken to be the focal point of the discussion, and the comprehension of conversational implicatures refers to "the ability to (a) recognize a mismatch between the literal utterance and the intention of the utterance and (b) comprehend the intention of the utterance" (Taguchi, 2008, p. 435). The premise of studying implicature, which blurs the line between what is literally said and what is conveyed, is to develop the ability to communicate effectively and appropriately in intercultural situations and reduce the possibility of pragmatic failures.

Bouton (1994b, 1999), considered a pioneer in developing a test of implicature knowledge, investigated the concept thoroughly and, subsequently, proposed a taxonomy for conversational implicatures, in which he distinguished two subcategories: formulaic implicatures and idiosyncratic implicatures. The interpretation of formulaic implicatures is based on a structural, semantic, or pragmatic formula and includes pope questions, indirect criticism, and irony. In the pope $\mathrm{Q}$ implicature, a person violates the relevance maxim by responding to a YES/NO question with another question. If the person asking the first question knows the answer to the second question, the implicature will be understood as it is the same answer to the first one. Indirect criticism implicature is commonly used when the evaluation is unfavorable in response to a request for assessment. In an effort to avoid being offensive or overtly critical, the speaker praises some insignificant aspect of the item he/she has been asked to evaluate to indicate that there is nothing else to be appreciated. Irony arises from the violation of the quality maxim when the listener looks for a different meaning that varies from the actual words in an attempt to confront the interlocutor with the opposite of what has been stated. On the other hand, idiosyncratic implicatures depend primarily on a mutual perception of the context and result from violations of the Gricean relevance maxim. This typology includes relevance-based implicatures, topic change, and disclosure. Relevance-based implicatures arise from responses that violate the relation maxim. In such cases, the interlocutor seeks a new meaning beyond what is said, which is relevant to the particular exchange and its context. Topic change implicatures are related to answers that totally change the topic. Disclosure implicatures deal with replies that disclose something about oneself.

With conscious acknowledgment of the role of pragmatic competence in communicative skills, especially in the field of implied meaning, many L2 cross-sectional studies have explored L2 learners' pragmatic performance in communicative environments (Bouton, 1994b; Ying, 2001; Cook \& Liddicoat, 2002; Takahashi, 2010a). Findings of these studies have conclusively indicated that pragmatic inferential skills are difficult to acquire for SL/FL learners even after prolonged TL exposure. While learners of high proficiency have shown major difficulties in understanding non-conventional indirect implicatures, learners of the low proficiency have had difficulties with both conventional and conversational implicatures (Cook \& Liddicoat, 2002). In addition, L2 learners' culture and language background have been demonstrated to considerably influence their perception of 
implied meaning, implying that the interpretation of implicatures could differ cross-culturally. Other studies have concluded that formal instruction can expedite the learnability of most types of conversational implicatures (Bouton, 1994b; Lee, 2002; Taguchi, 2008), thus improving EFL learners' intercultural communication skills to appropriately communicate with native speakers as well as with other language users, thereby allowing them to integrate into the TL culture to a greater extent (Roever, 2012).

Despite these theoretical grounds, instruction in pragmatic implicatures has not been widely carried out in EFL contexts and, thus, awaits research. The question remains, however, as to whether factors such as approaches to teaching pragmatic competence can predict gains in the development of conversational implicature comprehension. Given the positive results of the flipped model of instruction with some language skills, it is worth investigating its efficiency in the area of pragmatics, given that it is one of the basic building blocks of communicative competence.

\subsection{Flipped Classroom}

The flipped or inverted classroom is a modern pedagogical model that reshapes conventional teaching protocols in the classroom by concentrating on the learner and learning with the aid of technology. More specifically, practices that are primarily conducted in class (e.g., content presentation) become home activities delivered by the use of technology, and tasks and assignments that are usually done at home become classroom activities, thereby resulting in more class time devoted to communication (Bergmann \& Sams, 2012; Sohrabi \& Iraj, 2016). Flipped classrooms are grounded in a set of student-centered learning hypotheses that emphasize active learning, peer-assisted learning, and collaborative learning (Bishop \& Verleger, 2013). In the flipped classroom, the instructor takes on the role of facilitator rather than just providing information, while learners are fully responsible for their own educational process and learning rate, with the help of modern technological advances such as discussion boards and social networking sites (Lai \& Hwang, 2016). In flipped learning in L2 classrooms, technology is merely intended to allow more class time to be assigned to meaningful interaction to help learners gain a higher degree of language proficiency (Witten, 2013). As with all new curricula designs, the rationale for the flipped approach is to improve the quality and quantity of learning via student-centered activities.

The benefits of flipped learning, as documented by various researchers and educational experts in the field, can be interpreted as concrete evidence of its huge impact on pedagogical development (for a review see Akçayır \& Akçayır, 2018; Cheng, Ritzhaupt, \& Antonenko, 2019). First, the flipped approach allows teachers to allocate class time for communication by involving students in various interactive learning tasks, such as discussions, problem-solving, critical thinking, and hands-on activities. It shifts students' roles from passive lecture listeners to active participants through implementing active learning strategies and presenting opportunities to carry out higher-order thinking tasks. The role of teachers is, therefore, to direct, advise, and troubleshoot when needed during the class hour (Lai \& Hwang, 2016). The benefits of this role were highlighted by Bergmann and Sams (2012), who reported that spending less time delivering the course material and acting as a learning mentor in the flipped classroom is much easier for teachers and more interesting for students. Given this atmosphere, the flipping technique helps to improve teacher-student relationships and encourages students to learn more effectively. Second, as flipped models are mainly dependent on technological means to transfer curriculum presentations outside the classroom in the form of online recorded videos, students are freely allowed to view course content at home, where they can pause, rewind and prepare their questions for class discussion. This procedure increases students' engagement, performance, and motivation, which, in turn, accelerates academic achievement (Yu \& Wang, 2016). In addition, flipped classrooms motivate students to work together and participate in collaborative learning groups that empower them with self-directed learning skills (Tucker, 2012). Third, the flipped technique is believed to be of particularly great value to FL learners as it helps to overcome the inherent constraints of an FL setting in two respects: first, it prompts the integration of authentic audiovisual input that encompasses rich sources of information on language use as pre-class online learning, and second, it offers abundant opportunities for effective simultaneous communication within the classroom. Extended TL exposure and collaborative classroom interaction, resulting from the flipped strategy, can eventually foster learners' language proficiency and communicative competence (Witten, 2013). In his study, Nguyen (2018) acknowledged the efficacy of flipped teaching in enhancing communicative language skills as most participants reported having more opportunities to practice their English language skills compared to conventional classes. Not only did they gain more linguistic knowledge, but they also increased their intellectual growth by having more time for critical thinking and reflection activities, enabling them to be active students and decisive evaluators. This is in line with the deduction of Newman et al. (2016) that "flipped teaching affects students' knowledge acquisition involving information communication, information accessibility, information stimulation, information interaction and information accumulation" (p. 67). 
While most researchers have agreed throughout the history of FL teaching that pedagogical practices make a difference in language learning (Haight, Herrom, \& Cole, 2007), accounts of the application of flipped learning on students' achievements and perceptions in foreign language classes are still scarce (Cheng et al., 2019). Far too little attention has been paid to flipped classrooms in the Arab world in general and Saudi context in particular. Recently, Alharbi (2015) introduced the flipped classroom model to improve health informatics education, and collected qualitative data based on 14 EFL learners' attitudes. He concluded that this model provides many advantages to EFL learners, which include accelerating students' engagement, overcoming time constraints, and introducing videos of real-life situations that can promote language learning. Likewise, AlZahrani (2015) conducted a study on higher education students and found that although students faced some difficulties when implementing the flipped classroom approach due to limited training for this approach, the flipped classroom model promoted students' creative thinking. The above finding is consistent with the study of Al-Harbi and Alshumaimeri (2016) which addressed the influence of using the flipped strategy on the Grammar classroom. Twenty EFL students had to review some selected videos based on their textbook before each lesson and prepare their questions for discussion in class. Despite the initial challenges in adapting themselves to this new approach, the flipped group participants considerably outperformed the conventional group and perceived the flipped learning experience positively.

Unlike the above-mentioned studies, Hung (2017) explored the impacts of three different formats for flipped teaching: a structured flipped classroom, a semi-structured flipped classroom, and a non-flipped classroom utilizing a WebQuest active learning strategy. Experimental results showed that both structured and semi-structured flipped lessons were more interesting and stimulating to English learners than the non-flipped ones. In the same vein, Amiryousefi (2017) investigated the effect of the flipped classroom approach on EFL learners' speaking and listening skills. He also reported positive influences on students' EFL learning process resulting from out-of-class preparation and in-class engagement. In line with the previous studies, Ekmekci (2017) contrasted flipped and conventional face-to-face classes regarding students' writing skills and found that flipped-classroom students consistently surpassed their conventional counterparts after treatment. Additionally, the flipped experience had a positive effect on students' attitudes. Using a mixed-methods research approach, Chen Hsieh et al. (2017) investigated the impact of the flipped instructional method on the use of idioms among 48 EFL students. The flipped group participants learned idioms that the teacher shared through the LINE app, whereas the control group was instructed in a traditional manner. The conclusions suggested not only improvement in idiomatic knowledge and students' engagement but also higher motivation levels. In the same vein, Haghighi et al. (2019) explored the effect of the flipped model of instruction on Iranian EFL learners' appropriate pragmatic use of refusal. Sixty EFL learners were distributed into two groups: flipped and conventional. In the flipped class, the course content was uploaded before class via the telegram application, and class time was primarily dedicated to communicative tasks. The procedure for the conventional group, however, was dependent on regular instruction. In accordance with the previous literature, post-test findings indicated that flipped-learning participants outperformed their counterparts significantly in terms of pragmatic knowledge, engagement, and motivation for learning. Similarly, Hazaymeh and Altakhaineh (2019) examined the effectiveness of flipped learning on developing Emirati EFL learners' pragmatic use of requests. The findings demonstrated that the flipped group participants' performance on the speech act of request improved considerably in the posttest.

In sum, earlier research has highlighted the potential positive effects of the flipped model in language classes but has also revealed several research gaps. First, apart from its pedagogical value, few studies have further investigated the impact of the flipped approach on language learning in FL classrooms. The concept of flipped learning does not appeal to every society due to contextual differences (Muldrow, 2013). Accordingly, outcomes cannot be generalized unless comprehensive empirical investigations have been carried out in different contexts and fields of study. Second, drawing on the above-mentioned review, findings on the teachability of conversational implicatures and pragmatic inferential skills are very scant and inconclusive. Third, with the exception of Haghighi et al. (2019), no previous study has explored the effectiveness of the flipped approach on pragmatic competence. To the best of the present researcher's knowledge, to date, there is still no available empirical study investigating the influence of the flipped model of instruction on the development of Saudi EFL learners' comprehension of pragmatic conversational implicatures. Accordingly, the present study aimed to fill in these research gaps via this experimental research.

\section{Method}

The study utilizes a pre/post-test experimental and control design in an attempt to examine the effectiveness of a flipped classroom in promoting Saudi EFL students' comprehension of conversational implicatures. There are 
two independent variables called flipped instruction and traditional instruction as well as a dependent variable, which is the ability to comprehend conversational implicatures.

\subsection{Participants}

A total of 100 Saudi female EFL students matriculating at Prince Sattam bin Abdulaziz University were allocated randomly to two groups: "flipped classroom" $(\mathrm{n}=50)$ and "traditional classroom" $(\mathrm{n}=50)$. The participants, ranging from 21 to 23 years of age, were enrolled in a three-credit course called Discourse Analysis. The students had no previous experience of studying abroad nor had been exposed to any pragmatics course before the intervention; therefore, the experiment constituted their first exposure to pragmatic knowledge. Participants were well acquainted with the Edmodo website and did not need any training in the application's functionality.

\subsection{Instruments}

Three quantitative tests were used in each group: an English proficiency test known as the Oxford Placement Test (OPT), a pre/post-test, which was a multiple-choice discourse completion test (MDCT), and reflective e-portfolios.

\subsubsection{Oxford Placement Test}

The OPT was used to select participants from a population of 130 (Allen, 2004). It is a standardized and validated proficiency test published by Oxford University Press. The test's internal reliability was calculated and considered acceptable, as shown by the Cronbach's alpha coefficient of .83. Students of an intermediate level were randomly allocated to flipped $(\mathrm{N}=50)$ and traditional $(\mathrm{N}=50)$ groups as this level was regarded as the most appropriate level for teaching pragmatic knowledge (Kasper, 2001).

\subsubsection{Discourse Completion Test}

The study aimed to explore the effectiveness of the flipped model of instruction on EFL students' ability to comprehend conversational implicatures. Comprehension of conversational implicatures refers to "the ability to (a) recognize a mismatch between the literal utterance and the intention of the utterance and (b) comprehend the intention of the utterance" (Taguchi, 2008, p. 435). In order to collect data on EFL students' ability to comprehend implied meaning, a modified version of a multiple-choice discourse completion test was used (MDCT) (Bouton, 1994a, 1999; Taguchi, 2008, 2019; Roever, 2012; Çetinavci, \& Öztürk, 2017). The MDCT was piloted with 30 students to render the test more appropriate for the context of the study. The MDCT consisted of 27 items: four pope question items, four indirect criticism items, four verbal irony items, four topic change items, four disclosure items, four relevance items, and five filler items (see Appendix A). For content validity, the research tool was examined by five university professors who were experts in the field; two of them were native speakers of English. The data were analyzed with SPSS 22. Cronbach's alpha reliability coefficient was calculated to be 81 .

\subsubsection{Reflective E-Portfolio}

To assess the level of involvement of the flipped group students with the out-of-class study materials, participants were required to maintain six reflective e-portfolios in their Edmodo backpack library designed primarily to assess students' participation level with the content delivered for online learning outside the class. An e-portfolio "is essentially an electronic version of a paper-based portfolio, created in a computer environment" (Butler, 2006, p. 10). Research has documented that students do better in language courses if they complete more e-portfolio tasks. E-portfolios are extremely efficient regarding storage and much easier to manage and store than paper portfolios (Kimball, 2003). Moreover, it enhances learners' self-directed learning abilities to organize data, make decisions about learning, and have a well-structured view of their learning growth (Knight, Hakel, \& Gromko, 2006). Furthermore, the e-portfolio is an instrument of reflective practice that contributes to more informed reflection on the strengths and weaknesses of learners and promotes communication between students and teachers (Chau \& Cheng, 2010). The e-portfolio has been shown to be conducive to the production of transferable skills useful in academic programs and future careers (Lumsden, 2007).

The e-portfolio activity was initiated by adapting the backpack feature of Edmodo, which is a learning management system (LMS) that aims to provide teachers with tools to connect and communicate with their students and their parents and share content, videos, homework, and assignments online with them. Over the course of the entire semester, students in the flipped group were obliged to submit six e-portfolios, and immediate electronic feedback on the students' work was delivered before class. These reflective e-portfolios included three questions: introduce the type of implicature with a label, define it, and provide examples based on the study materials uploaded prior to each lecture. The rationale behind this online task is twofold; first, to gauge students' performance and development, and second, to confirm that students are engaged outside the classroom 
and having opportunities for self-learning and self-reflection in response to the teacher's comments. This activity allowed the teacher-researcher to check students' progress every two weeks. The students were awarded 12 marks based on their performance on the six e-portfolios as part of their coursework during the semester.

\subsection{Procedure}

Using a pre/post-test design, the process of collecting the data took one semester. At the beginning of the semester, 100 level-eight English students were distributed into two classes: flipped and traditional. The participants were enrolled in a three-credit-hour course entitled Discourse Analysis at the department of English at Prince Sattam bin Abdulaziz University. The pre-test was administered in the second week of the semester, and the post-test was administered in the 15th week of the semester. The instructional targets were six types of conversational implicatures, of which each type was covered in two sessions over 14 weeks. Upon completion of the pre-test, the participants in the flipped class received an orientation on the flipped model of instruction, which would be used for the treatment. They were further introduced to the Edmodo online platform and provided with the Edmodo group code for pre-class preparations and online learning. Students were familiar with the Edmodo website and did not need any training in the application's functionality.

Prior to class, students were required to review the online content of each session, which included a short instructional lecture recording followed by a short video representing the type of implicature and brief educational handouts for the assigned lesson. All these information resources were uploaded to the Edmodo online platform a week before each in-class session and kept available after the class so that students could access course content at their own pace, rewind, pause to take notes on key points, and review whenever they wanted. On Edmodo, students were encouraged to ask questions, offer feedback to their peers, and share videos related to the issue being discussed. They also had to maintain reflective e-portfolios in their Edmodo backpack library, which were awarded 12 marks as part of the coursework during the semester. The e-portfolios contained three questions based on the uploaded videos and readings of the targeted implicature designed, primarily, to assess the students' involvement with the out-of-class materials. The e-portfolios were to be submitted before class, and immediate electronic feedback was offered. In addition, the students were responsible for accessing Edmodo for details on the course description, course syllabus, experiment program, requirements, and evaluation schedule. The students had the possibility to contact their teacher-researcher whenever they needed any assistance.

During in-class sessions, students were required to reflect on theoretical frameworks, ask questions for collaborative discussions, negotiate issues to resolve any misconceptions, and clarify vague points pertaining to what they learned from the online instructional content at home. Next, students were given a worksheet to complete planned interactive tasks for the designated type of implicature under study. The task questions, adapted from Ishihara's book (2010) on how to teach implied meaning, Broersma's (1994) study, and Bouton's (1999) study, included identifying the implicature, explaining how literal meaning did not hold and how the implicature was identified, recognizing what the message actually implied, and giving a similar implicature in the student's L1 (pp. 154-155). The teacher provided immediate feedback on students' answers, cleared up misconceptions, and analyzed their L1 examples of implicatures. The assigned time for each session was 40 minutes. At the end of the session, the students were grouped to role-play some implicature examples they had already studied. After that, the students had to complete other topics related to the course description. Students were further provided with an online quiz after each class to confirm their understanding, for which they received automated feedback on their answers.

Students in the control group received regular course lectures with a metapragmatic instruction on conversational implicatures supported by PowerPoint presentations about the points under study. The students were required to listen attentively and then attempt some activities collaboratively if time permitted. The teacher-researcher was responsible for delivering all theoretical concepts in class; therefore, the students were not required to do any readings before class nor do any online activities after class.

\subsection{Data Analysis}

Using the statistical software SPSS, the data gathered through the tests mentioned above were analyzed. To answer RQs 1 and 2, paired-samples t-tests were carried out to provide an account of the progress of the flipped and control groups from the pre-test to the post-test in terms of their comprehension of the intended speech act. Next, an independent-samples t-test was run to compare the post-tests of the flipped and traditional groups. To code the identification of conversational implicatures in the pre/post-MDCT, each response in the MDCT earned a point value, and for each participant, total scores were estimated based on a total of 22 points as the filler items were excluded from the analysis. 
Regarding the third research question, students' engagement level in the flipped group, a reflective e-portfolio was used as a follow-up activity every two weeks (six in total) to determine students' engagement outside the classroom. In each e-portfolio task, the flipped group participants were expected to achieve three learning outcomes; (1) labeling the intended conversational implicature, (2) use of appropriate definitions to describe the target feature, and (3) use of concise structures to provide examples of the target feature. For each learning outcome, the students were graded on three levels of competence ranging from "Poor," meaning "in need of further work," "Good" meaning "outcome achieved well," to "Quite Good," meaning "outcome satisfactorily achieved," represented by the scores 1 to 3 . This discrete numerical rubric made performance quantitatively measurable so that the teachers could respond to the strengths and weaknesses displayed in students' work. Teachers were also able to enhance teaching and learning on the basis of students' learning outcomes (Mertler, 2016). After that, the reflective e-portfolios were compared in terms of two phases; the first phase (the first six weeks), during which participants had submitted three e-portfolios, was compared to the last three e-portfolios submitted in the last period of the treatment. Descriptive statistics were then used to demonstrate the mean scores of the participants for each item of the reflective e-portfolios in the two phases to determine significant differences and progress. Qualitative analysis was used to verify the effectiveness of the flipped approach.

\section{Results}

\subsection{The Effect of the Flipped Classroom Instruction on Pragmatic Comprehension}

In response to RQs 1 and 2, examining the effect of the flipped approach on developing Saudi EFL students' pragmatic comprehension of conversational implicatures and comparing two mediums of instruction (flipped vs. traditional), a paired-samples t-test was carried out to compare the pre- and post-tests in the flipped and traditional groups before and after the intervention. The results in Table 1 suggest that all participants had a statistically significant outperformance on the post-test $(p<.005)$ in contrast to the pre-test. This finding indicates that both methods of instruction were beneficial in enhancing the pragmatic abilities of EFL students during the entire semester.

Table 1. Paired-samples t-test for flipped and control groups

\begin{tabular}{llllll}
\hline & \multicolumn{2}{l}{ Paired differences } & & \\
\cline { 2 - 6 } & Mean & SD & t & df & Sig. (2-tailed) \\
\hline Flipped Pre/post-test & 8.34 & 5.47 & 12.90 & 20.88 & .000 \\
Traditional Pre/post-test & 3.58 & 3.92 & 5.88 & 18.49 & .000 \\
\hline
\end{tabular}

The results were further compared through an independent-samples t-test in an attempt to determine whether there was a statistically significant difference between the pre- and post-test scores of both the flipped and traditional groups before and after the experiment. Table 2 illustrates that there was no statistically significant difference between the flipped $(\mathrm{M}=10.14)$ and control $(\mathrm{M}=11.1)$ groups in terms of pragmatic knowledge $(\mathrm{t}=1.05$; $\mathrm{p}=.293>0.05$ ) prior to any intervention, and this result is consistent with the purpose of the study.

Table 2. Independent-samples t-test for the difference in the mean scores of the flipped group and the control group on pre-test

\begin{tabular}{lllllll}
\hline Group & $\mathrm{N}$ & Mean & SD & $\mathrm{t}$ & $\mathrm{df}$ & Sig. (2-tailed) \\
\hline Flipped & 50 & 10.14 & 4.62 & 1.05 & 49 & .293 \\
Traditional & 50 & 11.1 & 4.46 & & 49 & \\
\hline
\end{tabular}

Comparing the post-tests, the results of an independent-samples t-test, shown in Table 3, indicate that the mean score of the flipped group $(\mathrm{M}=18.48)$ was considerably higher than that of the traditional group $(\mathrm{M}=14.68)$; this difference is statistically significant $(p=.000[<0.05])$. The significant increase in the mean score of the flipped group reveals that while both mediums of instruction facilitated the development of participants' pragmatic competence, there is the potential to accelerate the development of EFL students' pragmatic inferential skills through the implementation of the flipped approach in EFL classrooms. Hence, the effectiveness of flipped learning over the traditional teaching method is supported in contributing to better learning outcomes in comprehending pragmatic conversational implicatures. 
Table 3. Independent samples t-test for the difference in the mean scores of the flipped group and the control group on post-test

\begin{tabular}{lllllll}
\hline Group & $\mathrm{N}$ & Mean & SD & $\mathrm{t}$ & $\mathrm{df}$ & Sig. (2-tailed) \\
\hline Flipped & 50 & 18.48 & 1.90 & 6.13 & 50 & .000 \\
Traditional & 50 & 14.68 & 3.94 & & 50 & \\
\hline
\end{tabular}

\subsection{Students'Engagement Level in the Out-of-Class Task}

The aim of the third study question was to determine students' level of involvement in the flipped model of instruction prior to class, as reflected in the total scores students had obtained in response to the questions in their reflective e-portfolios. Table 4 presents the mean and standard deviation of scores in response to the first three e-portfolios (150 in total) in the first phase of the treatment in comparison to the scores of the second phase. It is evident from the table below that the participants' pragmatic comprehension improved, with an increased mean score of (7.24). The p-value (19.76) implies a difference in statistical significance between the scores of the first phase and the second. The data suggest that doing more e-portfolios led to higher achievement in the flipped learning model. The comprehension of the flipped group participants improved significantly as the study progressed. The e-portfolios encouraged students of the flipped group to take responsibility for their own learning and study the course materials outside the class. Accordingly, e-portfolios were helpful in stimulating students to pursue independent learning and promoted their self-directed learning skills, contributing to the development of pragmatic knowledge and the comprehension of conversational implicatures.

Table 4. Descriptive statistics of students' scores in the e-portfolios

\begin{tabular}{lllllll}
\hline Flipped Group & $\mathrm{N}$ & Mean & $\mathrm{SD}$ & $\mathrm{t}$ & $\mathrm{df}$ & Sig. (2-tailed) \\
\hline First phase & 50 & 4.18 & 0.69 & 19.76 & 67.71 & .000 \\
Second phase & 50 & 7.24 & 1.07 & & & \\
\hline
\end{tabular}

\subsection{Discussion}

The present study aimed to examine the potential impact of flipped learning on Saudi EFL students' pragmatics competence and their engagement with course content via online learning through the Edmodo platform. The main findings can be summarized as follows: (1) EFL learners performed significantly better on the post-test than they did on the pre-test; (2) the flipped group participants considerably outperformed the traditional group participants on the MDCT post-test; (3) students' participation level with the online experiment materials escalated dramatically in the second phase of learning; (4) the Edmodo website proved to be a suitable learning platform for flipped learning; and (5) effective instruction of pragmatic conversational implicatures was possible in the Saudi context.

The results of the present study appear to be compatible with the research studies conducted by Alharbi (2015), Al- Zahrani (2015), Al-Harbi and Alshumaimeri (2016), Hung (2017), Amiryousefi (2017), Ekmekci (2017), and Chen Hsieh et al. (2017), in which the flipped group learners consistently outperformed their non-flipped group counterparts. Nevertheless, the above-mentioned studies were conducted to assess the effectiveness of the flipped model on certain language skills, such as speaking, listening, writing, and reading, whereas the current study seems to be the first to investigate the impact of inverted learning on interlanguage pragmatics, with the exception of the study of Haghighi et al. (2019), which explored the effect of flipped learning on Iranian EFL learners' appropriate pragmatic use of refusal. This study differs from Haghighi et al. (2019) in several aspects. The present study scrutinizes the impact of the flipped model on promoting the pragmatic competence of Saudi EFL learners, a different EFL context. Secondly, the focal aspect under study is conversational implicatures, which represent a relatively underrepresented area of investigation (Taguchi, 2019). Furthermore, the Edmodo website, rather than telegram, was used as the online platform for sharing the course content. Finally, a reflective e-portfolio, rather than a study log, was used to analyze the flipped group participants' preparations quantitatively before class. The results are in line with Hung (2017) and Chen Hsieh et al. (2017), who reported that students in flipped classrooms were more involved with the out-of-class course content compared to their traditional group counterparts. The findings also support Amiryousefi (2017) and Ekmekci (2017), who revealed more active engagement and participation inside the classroom for flipped classroom students than for those in the traditional classroom. In the same vein, the field notes of Chen Hsieh et al.'s (2017) study demonstrated greater fluency and accuracy in language comprehension and production among flipped group learners. 
The major influence of flipped model instruction is accounted for by what Bishop and Verleger (2013) called constructive learning, wherein stimulating cognitive processes of a higher order, such as critical thinking, problem-solving, and decision-making, will motivate language learners to deliberately draw on what they already know to reflect on what they are meant to learn and practice. As shown in the study statistics, students in the flipped classroom were more active participants in the learning process as opposed to the students in the traditional classrooms, who played a passive role (Lai \& Hwang, 2016). Another critical factor in the efficacy of the flipped approach is the quality of time spent inside the classroom compared to traditional classes (Davies, Dean, \& Ball, 2013). In the traditional classroom in the present study, the teacher-researcher was supposed to present and describe every type of implicature, explain every concept, give examples, and conduct pertinent activities whenever possible. Accordingly, class time was chiefly dedicated to lecturing and explaining. Thus, only a very small amount of time was left for the communicative use of the speech act. On the other hand, time in the flipped classroom was fully allocated to tasks that facilitated the comprehension and use of the speech act under investigation and reinforced the learners' competence through real-life communication. Using the Edmodo platform, the accessibility of lecture recordings, video clips, and other instructional materials might also have contributed to the dramatic increase in the post-test scores of the flipped group participants. It is acknowledged, as Tucker (2012) stated, that implementing new technologies may boost learners' motivation to work together and engage in collaborative learning, thereby empowering them with self-directed learning skills. In a similar vein, introducing e-portfolios into language learning helps students make connections between learning experiences. As an instrument of reflective practice, Chau and Cheng (2010) argue that e-portfolios contribute to a more informed reflection by learners on their strengths and weaknesses and promote communication between students and teachers. Furthermore, they encourage students to engage more in autonomous and independent learning. This may constitute a key aspect in the significant improvement of the flipped group participants of the current study.

There are certain limitations of this study that should be considered. First, the study was conducted on Level 8 university students. A duplication of this experiment with students of other levels could be conducted to ensure that the results were not compromised by any bias. Second, this seems to be the first study to investigate the impact of the flipped model on EFL learners' conversational implicatures and the second experiment to examine the effectiveness of flipped learning on the pragmatic development of EFL students. While the findings provide persuasive proof to promote the application of flipped learning to pragmatic instruction, additional research is required to generalize the results beyond the study contexts. Environmental factors of the study population may have influenced the study findings. Third, as mentioned earlier, the experiment was limited to female participants as the study was conducted at a female college. Gender differences can produce different outcomes. Furthermore, the present study sought to explore the effectiveness of the flipped model of instruction on learning speech-act implicatures. Future research in this study field may concentrate on the instruction of other types of speech acts or other pragmatic features.

\section{Conclusion}

In conclusion, the current study aimed to explore the effectiveness of the flipped model of instruction on the pragmatic development of conversational implicatures. The results of the study have several noteworthy pedagogical implications for the educational system. First, the flipped model can be an effective method for pragmatic instruction in EFL contexts. The integration of flipped learning into language learning leads to better learning outcomes, as indicated by the impressive achievement of the flipped group students. Second, the success of the flipped model of instruction is dependent primarily on students' preparation before class and appropriate manipulation of time inside the class. Out-of-class activities promote autonomous learning and self-directed learning skills, whereas in-class activities provide opportunities for active collaboration and language communication. Finally, the Edmodo website has proven to be a suitable and effective teaching tool for language learning due to its ease of implementation and use.

\section{Acknowledgment}

The author is very thankful to all the associated personnel in any reference that contributed to this research including Prince Sattam bin Abdulaziz University (Deanship of Scientific Research) for their constant support, encouragement and guidance.

\section{References}

Akçayır, G., \& Akçayır, M. (2018). The flipped classroom: A review of its advantages and challenges. Computers \& Education, 126, 334-345. https://doi.org/10.1016/j.compedu.2018.07.021

Alcón-Soler, E. A., \& Pitarch, J. G. (2010). The effect of instruction on learners' pragmatic awareness: A focus 
on refusals. International Journal of English Studies, 10(1), 65-80. https://doi.org/10.6018/ijes/2010/1/113981

Al-Harbi, A. H. (2015). A Flipped Learning Approach Using Social Media in Health Informatics. Scientific Research, 6(13), 1466-1475. https://doi.org/10.4236/ce.2015.613147

Al-Harbi, S., \& Alshumaimeri, A. (2016). The Flipped Classroom Impact in Grammar Class on EFL Saudi Secondary School Students' Performances and Attitudes. English Language Teaching, 9(10), 61-80. https://doi.org/10.5539/elt.v9n10p60

Alsowat, H. (2016). An EFL flipped classroom teaching model: Effects on English language higher-order thinking skills, student engagement and satisfaction. Journal of Education and Practice, 7(9), 108-121.

Al-Zahrani, A. M. (2015) From passive to active: The impact of the flipped classroom through social learning platforms on higher education students' creative thinking. British Journal of Educational Technology, 46(6), 1133-1148. https://doi.org/10.1111/bjet.12353

Amiryousefi, M. (2017). The incorporation of flipped learning into conventional classes to enhance EFL learners' L2 speaking, L2 listening, and engagement. Innovation in Language Learning and Teaching, 13(2), 1-15. https://doi.org/10.1080/17501229.2017.1394307

Bachman, L. F. (1990). Fundamental considerations in language testing. Oxford, England: Oxford University Press.

Bardovi-Harlig, K. (2010). Pragmatics and second language acquisition. In R. Kaplan (Ed.), The handbook of applied linguistics (2nd ed., pp. 232-243). Oxford, England: Oxford University Press. https://doi.org/10.1093/oxfordhb/9780195384253.013.0016

Bardovi-Harlig, K. (2013). Developing L2 pragmatics. Language Learning, 63(1), 68-86. https://doi.org/10.1111/j.1467-9922.2012.00738.x

Bergmann, J., \& Sams, A. (2012). Flip your classroom: Reach every student in every class every day. Arlington: International Society for Technology in Education.

Bishop, J. L., \& Verleger, M. A. (2013). The flipped classroom: A survey of the research. Paper presented at the 120th ASEE Annual \& Exposition, Atlanta, USA.

Blake, R. J. (2013). Brave new digital classroom: Technology and foreign language learning (2nd ed.). Washington, D.C.: Georgetown University Press.

Bouton, L. F. (1994a). Can non-native speakers' skill in interpreting implicature in American English be improved through explicit instruction? A pilot study. In L. F. Bouton (Ed.), Pragmatics and language learning (Vol. 5, pp. 88-109). Urbana-Champaign, IL: University of Illinois, Division of English as an International Language.

Bouton, L. F. (1994b). Conversational implicature in a second language learned slowly when not deliberately taught. Journal of Pragmatics, 22(2), 157-167. https://doi.org/10.1016/0378-2166(94)90065-5

Bouton, L. (1999). Developing nonnative speaker skills in interpreting conversational implicatures in English. In E. Hinkel (Ed.), Culture in second language teaching and learning (pp. 47-70). Cambridge: Cambridge University Press.

Butler, P. (2006). A review of the literature on portfolios and electronic portfolios (eCDF ePortfolio Project). Mendeley Research Networks.

Çetinavci, U. R., \& Öztürk, I. (2017, December). The development of an online test to measure the interpretation of implied meanings as a major constituent of pragmatic competence. TOJET (Special issue for INTE 2017), 184-222.

Chau, J., \& Cheng, G. (2010). Towards understanding the potential of e-portfolio for independent learning: A qualitative study. Australian Journal of Educational Technology, 26(7), 932-950. https://doi.org/10.14742/ajet.1026

Chen Hsieh, J. S., Wu, W. C. V., \& Marek, M. W. (2017). Using the flipped classroom to enhance EFL learning. Computer Assisted Language Learning, 30(1-2), 1-21. https://doi.org/10.1080/09588221.2015.1111910

Cheng, L., Ritzhaupt, A. D., \& Antonenko, P. (2019). Effects of the flipped classroom instructional strategy on students' learning outcomes: A meta-analysis. Educational Technology Research and Development, 67(4), 793-824. https://doi.org/10.1007/s11423-018-9633-7 
Cook, M., \& Liddicoat, A. J. (2002). The development of comprehension in interlanguage pragmatics: The case of request strategies in English. Australian Review of Applied Linguistics, 25, 19-39. https://doi.org/10.1075/aral.25.1.02coo

Davies, R. S., Dean, D. L., \& Ball, N. (2013). Flipping the classroom and instructional technology integration in a college-level information systems spreadsheet course. Educational Technology Research \& Development, 61(4), 563-580. https://doi.org/10.1007/s11423-013-9305-6

Ekmekci, E. (2017). The flipped writing classroom in Turkish EFL context: A comparative study on a new model. Turkish Online Journal of Distance Education, 18(2), 151-167. https://doi.org/10.17718/tojde.306566

Fordyce, K. (2014). The differential effects of explicit and implicit instruction on EFL learners' use of epistemic stance. Applied Linguistics, 35, 6-28. https://doi.org/10.1093/applin/ams076

Grice, H. P. (1975). Logic and conversation. In M. Ezcurdia \& R. J. Stainton (Eds.), The semantics-pragmatics boundary in philosophy (pp. 47-59). London: Broadview Press.

Haghighi, H., Jafarigohar, M., Khoshsima, H., \& Vahdany, F. (2019). Impact of flipped classroom on EFL learners' appropriate use of refusal: Achievement, participation, perception. Computer Assisted Language Learning, 32(3), 261-293. https://doi.org/10.1080/09588221.2018.1504083

Haight, C. E., Herron, C., \& Cole, S. P. (2007). The effects of deductive and guided inductive instructional approaches on the learning of grammar in the elementary foreign language classroom. Foreign Language Annals, 40(2), 288-310. https://doi.org/10.1111/j.1944-9720.2007.tb03202.x

Han, Y. J. (2015). Successfully flipping the ESL classroom for learner autonomy. NYS TESOL Journal, 2(1), 98 109.

Hao, Y. (2016). Exploring undergraduates' perspectives and flipped learning readiness in their flipped classrooms. Computers in Human Behavior, 59, 82-92. https://doi.org/10.1016/j.chb.2016.01.032

Hung, H. T. (2017). Design-based research: Redesign of an English language course using a flipped classroom approach. TESOL Quarterly, 51(1), 180-192. https://doi.org/10.1002/tesq.328

Ishihara, N. (2010). Adapting textbooks for teaching pragmatics. In N. Ishihara \& A. D. Cohen (Eds.), Teaching and learning pragmatics: Where language and culture meet (pp. 145-166). London, UK: Longman Applied Linguistics.

Johnson, L., Adams, S., \& Cummins, M. (2012). NMC Horizon report: 2012 K-12 education. Austin, TX: The New Media Consortium.

Kasper, G. (2001). Classroom research on interlanguage pragmatics. In G. Kasper \& K. Rose (Eds.), Pragmatics and language teaching (pp. 33-60). Cambridge: Cambridge University Press. https://doi.org/10.1017/CBO9781139524797.006

Lai, C.-L., \& Hwang, G.-J. (2016). A self-regulated flipped classroom approach to improving students' learning performance in a mathematics course. Computers \& Education, 100, 126-140. https://doi.org/10.1016/j.compedu.2016.05.006

Lee, J. S. (2002). Interpreting conversational implicatures: A study of Korean learners of English. The Korea TESOL Journal, 5(1), 1-26.

Lumsden, J. A. (2007). Development and implementation of an e-portfolio as a university-wide program. In J. W. Garis \& J. C. Dalton (Eds.), E-portfolios: Emerging opportunities for student affairs (pp. 43-63). San Francisco: Jossey-Bass. https://doi.org/10.1002/ss.248

Mertler, C. A. (2016). Classroom assessment: A practical guide for educators. Routledge. https://doi.org/10.4324/9781315266756

Muldrow, K. (2013). A new approach to language instruction: Flipping the classroom. The Language Educator, $11,28-31$.

Newman, G., Kim, J., Lee, R. J., Brown, B. A., \& Huston, S. (2016). The perceived effects of flipped teaching on knowledge acquisition. The Journal of Effective Teaching, 16(1), 52-71.

Nguyen, T. (2018). Implementation of English flipped classrooms: Students' perceptions and teacher's reflection. International Journal of Research Studies in Language Learning, 7(3), 87-108. https://doi.org/10.5861/ijrsll.2017.1876

Pimmer, C., Mateescu, M., \& Gröhbiel, U. (2016). Mobile and ubiquitous learning in higher education settings. 
A systematic review of empirical studies. Computers in Human Behavior, 63, 490-501. https://doi.org/10.1016/j.chb.2016.05.057

Rafieyan, V., Sharafi-Nejad, M., Damavand, A., Lin, S. E., \& Abdul-Rashid, M. (2014). Relationship between emotional intelligence and pragmatic awareness. International Journal of Applied Linguistics \& English Literature, 3(4), 143-149. https://doi.org/10.7575/aiac.ijalel.v.3n.4p.143

Roever, C. (2012). What learners get for free (and when): Learning of routine formulae in ESL and EFL environments. English Language Teaching Journal, 66(1), 10-21. https://doi.org/10.1093/elt/ccq090

Sánchez-Hernández, A., \& Alcón-Soler, E. (2019). Pragmatic gains in the study abroad context: Learners' experiences and recognition of pragmatic routines. Journal of Pragmatics, 146, 54-71. https://doi.org/10.1016/j.pragma.2018.08.006

Shively, R. (2010). From the virtual world to the real world: A model of pragmatics instruction for study abroad. Foreign Language Annals, 43(1), 105-137. https://doi.org/10.1111/j.1944-9720.2010.01063.x

Sohrabi, B., \& Iraj, H. (2016). Implementing flipped classroom using digital media: A comparison of two demographically different groups perceptions. Computers in Human Behavior, 60, 514-524. https://doi.org/10.1016/j.chb.2016.02.056

Taguchi, N. (2008). The role of learning environment in the development of pragmatic comprehension: A comparison of gains between EFL and ESL learners. Studies in Second Language Acquisition, 30(4), 423452. https://doi.org/10.1017/S0272263108080716

Taguchi, N. (2015). Instructed pragmatics at a glance: Where instructional studies were, are, and should be going. Language Teaching, 48(1), 1-50. https://doi.org/10.1017/S0261444814000263

Taguchi, N. (Ed.). (2019). The Routledge Handbook of Second Language Acquisition and Pragmatics. Routledge. https://doi.org/10.4324/9781351164085

Takahashi, S. (2010a). Assessing learnability in second language pragmatics. In A. Trosborg (Ed.), Handbook of pragmatics (Vol. 7, pp. 391-421). Berlin: Mouton de Gruyter.

Takahashi, S. (2010b). The effect of pragmatic instruction on speech act performance. In A. Martínez-Flor \& E. Usó-Juan (Eds.), Speech act performance: Theoretical, empirical and methodological issues (pp. 127-144). Amsterdam/Philadelphia: John Benjamins.

Tucker, B. (2012). The flipped classroom. Education Next, 12(1), 82-83.

Turan, Z., \& Akdag-Cimen, B. (2019). Flipped classroom in English language teaching: A systematic review. Computer Assisted Language Learning, 1-17. https://doi.org/10.1080/09588221.2019.1584117

Wafa'A, H., \& Altakhaineh, A. R. M. (2019). The Effect of Flipped Classroom Instruction on Developing Emirati EFL Learners' Pragmatic Competence. International Journal of Learning, Teaching and Educational Research, 18(10), 89-111. https://doi.org/10.26803/ijlter.18.10.6

Witten, H. (2013). World languages. In J. Bretzman (Ed.), Flipping 2.0: Practical strategies for flipping your class (pp. 265-280). New Berlin, WI: The Bretzman Group.

Ying, H. G. (2001, February). Relevance mapping: A study of L2 learners 'processing of syntactically ambiguous sentences in English. Paper presented at the Annual Association for Applied Linguistics conference, St. Louis, Missouri.

Yu, Z., \& Wang, G. (2016). Academic achievements and satisfaction of the clicker-aided flipped business English writing class. Educational Technology \& Society, 19(2), 298-312. https://www.jstor.org/stable/jeductechsoci.19.2.298

Yule, G. (1996). Pragmatics. New York: Oxford University Press. 


\section{Appendix A}

\section{The MDCT item specifications}

Conversational implicature types

\begin{tabular}{ll}
\hline Fillers (5 items) & $1,7,13,19,24$ \\
Pope questions (4 items) & $3,9,14,22$ \\
Indirect criticism (4 items) & $2,11,17,25$ \\
Irony (3 items) & $4,10,21$ \\
Topic change (4 items) & $5,15,18,26$ \\
Disclosure (3 items) & $6,16,23$ \\
Relevance (4 items) & $8,12,20,27$ \\
\hline
\end{tabular}

The five filler items were excluded from the analyses as they dealt with the literal comprehension of direct interpretation. They were utilized as distracters to divert the participants' attention from the true purpose of the test, which is to investigate how test takers comprehend the nonliteral meanings. If the test had consisted of only implied interpretation items, participants who discover it after answering some initial questions could stop examining the rest and continue by just searching for the response options that give indirect meaning.

\section{Appendix B}

\section{Test items}

Name:

level:

\section{Item1:}

Bob and Sarah, two school friends, are halfway to finishing this semester. They are talking about the courses they are taking.

Bob: "By the way, how are you doing in history?"

Sarah: "Um ... not so well. I got a ' $C$ ' on the last test".

\section{What does Sarah probably mean?}

a) She is doing really well in history.

b) She loves history.

c) She is not sure about her performance.

d) She is not doing so well in history.

Item 2:

Mrs. Jackson and Mrs. White, two teachers, are talking about a student's research project named Mark.

Mrs. Jackson: "How did you like Mark's project?"

Mrs. White: "Well.... I thought it was well-typed".

\section{What does Mrs. White probably mean?}

a) She did not like Mark's research project.

b) She does not really remember Mark's research project.

c) She thought the topic Mark had chosen was interesting.

d) She liked Mark's research project quite a lot.

\section{Item 3:}

Barbara and Betty, two classmates, are talking about what they are going to do during the summer. Barbara's mother wants her to stay home and entertain the relatives when they come to visit them at the beach.

Betty: "Do you have a lot of relatives?"

Barbara: "Does a dog have fleas?"

\section{What does Barbara probably mean?}

a) She does not like her relatives and feels like an unlucky dog. 
b) She does not have very many relatives.

c) She has a lot of relatives.

d) She wants to learn if a dog usually has fleas.

\section{Item 4:}

Henry loves cycling. He orders a new, very expensive bicycle from a new bicycle company. When it arrives, he sees that it is really heavy and does not look well-made at all.

\section{Henry: "Wow, this company's really honest."}

\section{What does Henry probably mean?}
a) The company is dishonest.
b) The company is a tiny bit sneaky.
c) The company is a really honest one.
d) It is normal as the company is new.

\section{Item 5:}

Bob and Maggie, friends, are talking about school and courses. Bob is taking introductory chemistry this semester. Maggie: "How are you doing in chemistry?"

\section{Bob: "So ... did you watch that basketball game yesterday?"}

\section{What does Bob probably mean?}

a) The content of yesterday's lesson was completely irrelevant to chemistry like a basketball game.

b) He is doing badly in chemistry.

c) Chemistry is like an easy game for him.

d) He is doing so well in chemistry that there is no need to talk about it.

Item 6:

John's friend Mary asks him about their classmate Sally.

Mary: "You know. I've been curious to know if you went out with Sally."

John: "Um.... Sally's not really my type".

\section{What does John probably mean?}

a) He is not sure of his feelings.

b) He is talking bad about Sally as she refused him.

c) Mary is his type.

d) They did not go out.

\section{Item 7:}

Susan and John, friends, are watching a film together.

Susan: "This film is too boring! I can't watch it anymore."

\section{John: "Really? I don't think it's so bad".}

\section{What does John probably mean?}

a) He thinks the film is really bad.

b) He is doing something else, not watching the film.

c) He does not think the film is very bad.

d) $\mathrm{He}$ is not quite sure.

\section{Item 8:}

When Mark got home, he found that his wife had to use a walking stick in order to walk.

Mark: "What happened to your leg?"

Wife: "I went jogging". 


\section{What does Mark's wife probably mean?}

a) Today I finally got some exercise jogging.

b) I hurt it jogging.

c) It's nothing serious. Don't worry about it.

d) I hurt it doing something silly.

\section{Item 9:}

Maria and Frank are working on a class project together, but they will not be able to finish it by the deadline.

Maria: "Do you think Dr. Gibson is going to lower our grade if we hand it in late?"

\section{Frank: "Do fish swim?"}

\section{What does Frank probably mean?}

a) He thinks they should choose a new project topic on fish.

b) He thinks Dr. Gibson will not lower their grade.

c) He thinks they will get a lower grade.

d) He suggests just giving in the project to see the result.

\section{Item 10:}

Peter promises his friend Mary to help her move to a new apartment. That day, he moves the clock on the wall while Mary moves the heavy boxes.

\section{Mary: "Thanks, you've been terribly helpful."}

\section{What does Mary probably mean?}
a) Peter helped her a lot.
b) Moving the clock was really important as it needed special care.
c) Peter is weak.
d) Peter was not helpful at all.

\section{Item 11:}

Toby and Ally are trying a new buffet restaurant in town. Toby is eating something, but Ally cannot decide what to have first.

\section{Ally: "How do you like what you're eating?"}

Toby: "Well, let's just say it's... colorful".

\section{What does Toby probably mean?}
a) He thinks it is important for food to look good.
b) He likes the food.
c) He wants Ally to try something colorful.
d) He does not like the food much.

\section{Item 12:}

Susan and Emily are students sharing a flat in Sydney and are getting ready to go to class together.

Emily: "Is it very cold out this morning?"

Susan: "It's December".

\section{What does Susan probably mean?}

a) It will be nice and warm today. Don't worry.

b) Yes, even though it's December. It's very cold out.

c) It's so warm for this time of year that it seems like December.

d) Yes, we're sure having crazy whether, aren't we?

\section{Item 13:}


Paul and Mary, two friends, are having a talk. Paul remembers that he must pay his apartment's rent today but has no money for it now.

Paul: "Oh, the rent is due today, but I don’t get paid until Monday. Could I borrow \$50? I'll give it back next week." Mary: "Sure, no problem."

What does Mary probably mean?

a) She is not sure about giving money to Paul.

b) She will give the money to Paul.

c) It is a problem for Paul.

d) She will not give the money.

\section{Item 14:}

Susan and John, two officemates, are having lunch in a cafe and discussing their boss.

John: "So, do you think Mr. Davis will give me a raise?"

Susan: "Do pigs fly?"

What does Susan probably mean?

a) She wants to change the topic.

b) The boss will not give John a raise.

c) She has seen outside a pig falling down from a high place.

d) John will get a raise.

\section{Item 15:}

Hilda is looking for a new job. She is having lunch with her friend John.

John: "So how's the job search coming along?"

Hilda: "Um, this curry's really good, don't you think?"

\section{What does Hilda probably mean?}

a) She did not understand John's question.

b) She is not looking for a job anymore.

c) She wants to talk about nothing but food.

d) Her job search is not going very well.

\section{Item 16:}

Susan and Tom, friends, are talking about what is going on in their lives. Susan knows Tom had a job interview recently.

Susan: "So how was your interview? Did you get the job you applied for?"

Tom: "Um ... I think I need to improve my interview skills".

What does Tom probably mean?

a) He did not get the job.

b) He wants help from Susan to improve his interview skills.

c) He will have the interview when he feels his interview skills are good enough.

d) They gave him the job with the advice that he should improve his interview skills.

\section{Item 17:}

Ken bought a new car and he showed it to his co-worker, Tina. She drove it around for a couple of times and they are talking at lunchtime the next day.

Ken: "So what do you think of this new car?"

Tina: "Well, the color's fine".

What does Tina probably mean? 
a) What she liked most about the car is its color.

b) She thinks the color of a car is very important.

c) She does not know much about cars.

d) She did not like the car very much.

\section{Item 18:}

Jane is talking to her co-worker Brian during a coffee break.

Jane: "So, life must be good for you. I hear you got a nice raise."

Brian: "Um, this coffee is awfully weak. You'd think they'd at least give us decent coffee".

\section{What does Brian probably mean?}

a) He does not want to talk about how much money he earns.

b) He does not like the coffee.

c) Reality may not be what you think it is.

d) He does not care about money.

\section{Item 19:}

Joan and Dave, classmates, see each other in the school corridor.

Joan: "Hi Dave".

Dave: "Hi Joan. What's up?".

Joan: "I was going to ask you a favor. Would you read my paper for English 101?"

Dave: “Oh, Joan, sorry I can't. I have a class in about 10 minutes".

\section{What does Dave probably mean?}

a) He will read the paper.

b) That is a difficult thing to do for him.

c) He will read it after the class.

d) He will not read the paper because he is busy.

Item 20:

John is talking to his housemate Frank about another housemate, Sarah.

John: "Do you know where Sarah is, Frank?"

\section{Frank: "Well, I heard music from her room earlier".}

\section{What does Dave Frank mean?}
a) Sarah got to turn the music off.
b) Sarah's loud music bothers Frank.
c) Sarah is probably in her room.
d) Frank doesn't know where Sarah is.

\section{Item 21:}

Jenny is out in the freezing cold after college classes. As she often has to do, she has been waiting for her father to pick her up for an hour. She throws a quick glance at her watch, talking to herself.

\section{Jenny: "He's a bit late huh?"}

\section{What does Jenny probably mean?}

a) Her father is not very late yet.

b) She is anxious about her father.

c) Her father is really late once again.

d) She needs to look at her watch again. 


\section{Item 22:}

Rob is telling his friend Tom about a card game he played last night. He lost money and decides not to play with those guys again.

Tom: "They were good, huh?"

Rob: "Good? Let's say awfully lucky".

Tom: "Lucky? What's the matter? Don't you trust them?"

\section{Rob: "Is the sky green?"}

\section{What does Rob probably mean?}
a) He thinks they are OK.
b) He does not want to talk about the card game anymore.
c) He suddenly saw something in the sky.
d) He does not trust them at all.

\section{Item 23:}

Sally and Dennis, old friends, see each other again after a long time. Sally has heard that Dennis got divorced but she is not sure.

Sally: "By the way, is it true you got divorced?"

Dennis: "You know ... I think we got married too young".

What does Dennis probably mean?
a) They are still in that unhappy marriage.
b) They are not married anymore.
c) They are OK, but it would have been better if they had got married older.
d) He does not want to answer the question.

\section{Item 24:}

Tom is from Atlanta. His friend Sally has recently moved to Atlanta.

Tom: "How do you like Atlanta so far?"

\section{Sally: "I love it!"}

\section{What does Sally probably mean?}

a) She thinks that Atlanta is a dirty city.

b) She has not seen much of the city since she moved in.

c) She thinks the city needs more great changes.

d) She likes Atlanta and enjoys living there

\section{Item 25:}

Brenda and Sally, friends, have lunch every Tuesday. As they meet on this particular day, Brenda stops and twirls like a fashion model, smiling.

Brenda: "I just got a new dress. How do you like it?"

Sally: "Well ... it's certainly a popular style".

\section{What does Sally probably mean?}
a) Brenda should have bought it earlier.
b) She really likes it.
c) Every dress is the same for her.
d) She does not like it much.

\section{Item 26:}

Dale runs into his friend Julia. He knows Julia recently had a job interview. 
Dale: "By the way, did you get that job you applied for?"

Julia: “Good God, I'm so tired of this cold weather".

What does Julia probably mean?

a) She does not want to talk about the interview.

b) She is bored of searching for a job.

c) She did not understand Dale's question.

d) She could not attend the interview because of cold weather.

\section{Item 27:}

Jack wanted to know what time it was, but he didn't have a watch, so he asked Helen.

Jack: "What time is it, Helen?"

Helen: "The postman has been here"

Jack: "Okay. Thanks".

\section{What does Helen probably mean?}

a) She is telling him approximately what time it is by telling him that the postman has already been there.

a) By changing the subject, Helen is telling Jack that she doesn't know what time it is.

b) She thinks that Jack should stop what he is doing and read his mail.

c) Jack will not be able to interpret any message from what Helen says, since she didn't answer his question.

\section{Copyrights}

Copyright for this article is retained by the author, with first publication rights granted to the journal.

This is an open-access article distributed under the terms and conditions of the Creative Commons Attribution license (http://creativecommons.org/licenses/by/4.0/). 